\title{
Prognostic factors in pathological stage IB nonsmall cell lung cancer greater than $3 \mathrm{~cm}$
}

\author{
J-J. Hung*,\#, ", W-J. Jeng ${ }^{+}$, W-H. Hsuף, S-F. Lin ${ }^{\S}$, C-C. Hsieh*, , B-S. Huangף,

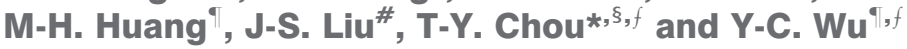

ABSTRACT: Significant heterogenity of stage IB (sixth edition of the TNM staging system) nonsmall cell lung cancer (NSCLC) has been identified, and further subclassification according to tumour size has been proposed. The aim of this study is to evaluate the prognostic factors in patients with resected stage IB NSCLC $>3 \mathrm{~cm}$.

From January 1980 to December 2000, 525 patients underwent surgical resection for stage IB NSCLC $>3 \mathrm{~cm}$ at Taipei Veterans General Hospital, Taipei, Taiwan. The clinicopathological characteristics of these patients were retrospectively reviewed.

The 5- and 10-yr overall survival rates were $44.9 \%$ and $27.3 \%$, respectively. Age $(p<0.001)$, tumour size $(p=0.002)$, extent of pulmonary resection $(p=0.002)$, histological type $(p=0.005)$ and number of mediastinal lymph nodes dissected/sampled $(p=0.004)$ were significant predictors for overall survival in multivariate analysis. Patients with tumour size $>7 \mathrm{~cm}$, or $>5$ to $\leqslant 7 \mathrm{~cm}$, had a worse survival than those with tumour size $>3$ to $\leqslant 5 \mathrm{~cm}$. However, visceral pleural invasion did not influence overall survival.

Stage IB NSCLC with a diameter $>3 \mathrm{~cm}$ may be subclassified according to tumour size regardless of visceral pleural invasion.

KEYWORDS: Nonsmall cell lung cancer, stage IB, survival, tumour size, visceral pleural invasion

ung cancer is the leading cause of cancerrelated death worldwide. Histological identification and tumour staging play a critical role for the optimal management of lung cancer. The Union Internationale Contre le Cancer was the first organisation to classify lung cancer by tumour, node, metastasis (TNM) staging system in 1968. The TNM staging system for lung cancer was first applied by the American Joint Committee on Cancer in 1974 [1]. The fifth edition of the TNM staging system for lung cancer was published in 1997, and stage I nonsmall cell lung cancer (NSCLC) was subdivided into IA (T1N0M0, tumour size $\leqslant 3 \mathrm{~cm}$ ) and IB (T2N0M0, tumour size $>3 \mathrm{~cm}$ ) [2]. In addition to tumour size $>3 \mathrm{~cm}$, the current T2 descriptor also includes tumours that invade the visceral pleura regardless of size, tumours that involve the main bronchus $\geqslant 2 \mathrm{~cm}$ distal to the carina, and tumours that result in associated atelectasis and obstructive pneumonitis that extends to the hilar region but does not involve the entire lung radiographically [2]. The current (sixth) edition of the TNM staging system for lung cancer was published in 2002 [3], without changes to the previous edition [2]. Significant heterogenity of stage IB patients has been identified in several studies, and further subclassification according to tumour size has been proposed [4-7]. The seventh edition of the TNM classification of lung cancer was published in 2009 [8,9]. The changes to the sixth edition of the TNM staging system for lung cancer were based upon the proposals from the International Association for the Study of Lung Cancer (IASLC). The IASLC lung cancer staging project committee has recommended that T2 tumours be classified into T2a $(>3$ to $\leqslant 5 \mathrm{~cm})$, T2b $(>5$ to $\leqslant 7 \mathrm{~cm})$, and T3 $(>7 \mathrm{~cm})$ [10-12].

Among the three non-size-based T2 descriptors, visceral pleural invasion (VPI) is the main criteria $[4,13,14]$. HAMmAR $[15,16]$ suggested a classification of pleural invasion as follows: Px and P0, lack of pleural invasion beyond the elastic layer; $\mathrm{P} 1$, invasion beyond the elastic layer; $\mathrm{P} 2$, invasion to the surface of the visceral pleura; and P3, invasion of the parietal pleura and/or chest wall. According to his proposal, P0 is not a T descriptor and the $\mathrm{T}$ category in such cases should be assigned by other criteria. P1 or P2 correspond to T2, and P3 corresponds to T3. The International Staging Committee of the IASLC has proposed the definition of VPI as invasion beyond the elastic layer (PL1) including invasion to the visceral pleural surface (PL2) [17]. They also recommend that elastic stains be used in
AFFILIATIONS

*Institute of Clinical Medicine,

National Yang-Ming University,

\#Dept of Surgery, Cathay General

Hospital and School of Medicine, Fu Jen Catholic University,

"Division of Thoracic Surgery, Dept of Surgery, Taipei Veterans General Hospital and School of Medicine, National Yang-Ming University, +Dept of Internal Medicine, Chang Gung Memorial Hospital and School of Medicine, Chang Gung University, §Dept of Pathology and Laboratory Medicine, Taipei Veterans General Hospital, Taipei, Taiwan.

${ }^{f}$ Both authors contributed equally to this study.

CORRESPONDENCE

Y-C. Wu

Division of Thoracic Surgery, Dept of Surgery

Taipei Veterans General Hospital No. 201

Section 2

Shih-Pai Road

Taipei 112

Taiwan

E-mail:wuyc@vghtpe.gov.tw

Received:

Jan 262009

Accepted after revision: May 032010

First published online:

June 012010 
cases when the distinction between PLO and PL1 is not clear based on evaluation of haematoxylin and eosin sections [17]. Although VPI has generally been reported to be a poor prognostic factor [18-23], some studies have demonstrated that VPI was not a prognostic factor for survival [4, 6, 7, 13, 24, 25]. The prognostic value of VPI in patients of early stage NSCLC with larger tumour size has remained to be demonstrated.

In our previous study [26], we demonstrated that VPI did not influence overall survival in resected stage I NSCLC with a diameter of $\leqslant 3 \mathrm{~cm}$. Therefore, we recommend that patients with tumour size $\leqslant 3 \mathrm{~cm}$ that are staged as stage IB (T2N0M0) due to VPI to be treated as stage IA (T1N0M0). According to our proposal, the category of stage IB NSCLC only consists of patients with stage I NSCLC with a diameter $>3 \mathrm{~cm}$. In this regard, we analysed the prognostic factors of survival in stage IB NSCLC with a diameter $>3 \mathrm{~cm}$ and evaluate the validity of the new staging system of $\mathrm{T}$ descriptors proposed by the IASLC. Furthermore, we investigated the prognostic value of VPI and its relationship with tumour size in these patients.

\section{MATERIALS AND METHODS}

From January 1980 to December 2000, a total of 597 patients underwent surgical resection for pathological stage IB (T2N0M0) NSCLC at Taipei Veterans General Hospital. Of these, $525(87.9 \%)$ patients who had tumours with a diameter $>3 \mathrm{~cm}$ were identified and included in this retrospective study. The pre-operative staging work-up, including chest and upper abdomen computed tomographic scans, bronchoscopic examination and nuclear medicine survey (bone and brain), was done as previously described [26, 27]. Mediastinoscopy was not a routine pre-operative staging procedure, and was performed only when enlarged mediastinal lymph nodes (diameter $>1.0 \mathrm{~cm}$ ) were shown by computed tomographic scan. Among the 194 patients with available data on whether preoperative mediastinoscopy was performed for staging, 12 (6.2\%) underwent mediastinoscopy before operation. In the study period, positron emission tomography scan was not available as a staging modality. Patients with suspected distant metastasis were excluded from consideration for operation. Complete resection of lung cancer with mediastinal lymph node dissection/sampling was performed in all patients as previously described [26, 27]. No patient received adjuvant chemotherapy after surgical resection. Histological typing was determined according to the World Health Organization classification [28]. Determination of disease stages was based on the TNM classification of the International Union Against Cancer [3].

VPI was examined in tumour sections with haematoxylin and eosin stain. VPI was classified according to the suggestion proposed by HAMMAR [15, 16]: Px and P0, lack of pleural invasion beyond the elastic layer; P1, invasion beyond the elastic layer; P2, invasion to the surface of the visceral pleura; and P3, invasion of the parietal pleura and/or chest wall. Presence of VPI was defined as tumours with P1 and P2, whereas absence of VPI was defined as tumours with Px and P0. Elastic stains were performed in tumour sections when the status of VPI was indeterminate by haematoxylin and eosin stains.

The hospital charts of all patients, including pathological and surgical reports, were reviewed to collect data of clinicopathological characteristics and survival. Patient demographics, pack-yrs, tumour location, histological type of the tumour, histological grade, tumour size $(>3$ to $\leqslant 5$ versus $>5$ to $\leqslant 7$ versus $>7 \mathrm{~cm}$ ), extent of pulmonary resection, presence of VPI and number of mediastinal lymph nodes dissected/sampled were documented. The number of mediastinal lymph nodes dissected/sampled, including N1 and N2 nodes, was recorded from pathological reports. All patients were followed up at our outpatient department quarterly in the initial 2 yrs after resection and semi-annually thereafter. The length of survival was defined as the interval in months between the date of surgical resection and the date of either death or the last follow-up.

The overall survival rate was calculated by the Kaplan-Meier method [29]. The Chi-squared test, the paired independent sample t-test, or the one-way ANOVA test was used to compare between groups with respect to categorical and continuous variables as appropriate. Univariate and multivariate analyses were performed by means of the Cox proportional hazards model using SPSS software (version 16.0; SPSS, Chicago, IL, USA). Variables with p-value $<0.05$ after the univariate analysis were entered into multivariate analysis. Statistical analysis was considered to be significant when $\mathrm{p}<0.05$.

\section{RESULTS}

The median follow-up time for these 525 patients with surgically resected stage IB NSCLC with a diameter $>3 \mathrm{~cm}$ was 50.3 months (95\% CI 43.8-58.0 months). The characteristics of these patients are listed in table 1 . There were 16 patients lost to follow-up. At the last follow-up session, 119 patients were alive (including five patients alive with recurrent cancers), 210 patients died of other causes without evidence of tumour recurrence, and 180 patients (34.3\%) died of cancer. 23 post-operative deaths $(4.4 \%)$ occurred, 10 patients with pneumonectomy, four with bilobectomy, five with lobectomy and four with wedge resection. The 5- and 10-yr overall survival rates were $44.9 \%$ and $27.3 \%$, respectively (fig. 1).

The relationship between clinicopathological characteristics and tumour size is listed in table 2 . The tumour size of $>3$ to $\leqslant 5 \mathrm{~cm}$ group consisted of more female patients than the $>5$ to $\leqslant 7 \mathrm{~cm}(\mathrm{p}=0.001)$ and $>7 \mathrm{~cm}(\mathrm{p}=0.023)$ groups. The group with tumour size of $>5$ to $\leqslant 7 \mathrm{~cm}$ consisted of higher number of pack-yrs than that of $>3$ to $\leqslant 5 \mathrm{~cm}(\mathrm{p}=0.001)$. The group with tumour size of $>3$ to $\leqslant 5 \mathrm{~cm}$ consisted of less squamous cell carcinoma than that of $>5$ to $\leqslant 7 \mathrm{~cm}(\mathrm{p}=0.001)$ and $>7 \mathrm{~cm}$ $(\mathrm{p}=0.001)$ groups. Patients with tumour size $>7 \mathrm{~cm}$ had a higher frequency undergoing pneumonectomy or bilobectomy than those of $>5$ to $\leqslant 7 \mathrm{~cm}(\mathrm{p}=0.009)$ and those of $>3$ to $\leqslant 5 \mathrm{~cm}(\mathrm{p}<0.001)$. No association between VPI $(\mathrm{p}=0.232)$ or other clinicopathological characteristics and tumour size was detected.

Univariate analysis indicated that age (hazard ratio (HR) 1.020, 95\% CI 1.008-1.033; $\mathrm{p}=0.001$ ), sex (HR of male 1.408, 95\% CI 1.057-1.880; $\mathrm{p}=0.019)$, pack-yrs (HR 1.004, 95\% CI 1.000-1.007; $\mathrm{p}=0.037)$, tumour size $(\mathrm{p}<0.001)$, and extent of pulmonary resection (HR for bilobectomy and pneumonectomy 1.374, 95\% CI 1.109-1.703; $\mathrm{p}=0.004)$ and number of mediastinal lymph node dissected (HR 0.988, 95\% CI 0.978-0.999; $\mathrm{p}=0.035$ ) had a significant influence on overall survival (table 3 ). The median 


\begin{tabular}{|c|c|c|}
\hline TABLE 1 & \multicolumn{2}{|c|}{$\begin{array}{l}\text { Characteristics of } 525 \text { patients of resected stage } \\
\text { IB nonsmall cell lung cancer with a diameter } \\
>3 \mathrm{~cm}\end{array}$} \\
\hline Variables & & Patients \\
\hline \multicolumn{3}{|l|}{$\begin{array}{l}\text { Age yrs } \\
\text { Sex }\end{array}$} \\
\hline \\
\hline Male & & 437 (83.2) \\
\hline Female & & $88(16.8)$ \\
\hline Smoking ex & osure pack-yrs & $27.2 \pm 25.2$ \\
\hline \multicolumn{3}{|c|}{ Tumour location } \\
\hline Right lung & & $385(73.3)$ \\
\hline Left lung & & $140(26.7)$ \\
\hline Tumour size & & $5.2 \pm 2.0$ \\
\hline$>3$ to $\leqslant 5$ & & $362(69.0)$ \\
\hline$>5$ to $\leqslant 7$ & & $111(21.1)$ \\
\hline$>7 \mathrm{~cm}$ & & $52(9.9)$ \\
\hline \multicolumn{3}{|c|}{ Histological type } \\
\hline Squamous & ell carcinoma & $272(51.8)$ \\
\hline Adenocarc & oma & $188(35.8)$ \\
\hline Bronchioal & olar carcinoma & $30(5.7)$ \\
\hline Large cell & arcinoma & $29(5.5)$ \\
\hline Adenosqua & nous carcinoma & $6(1.1)$ \\
\hline \multicolumn{3}{|c|}{ Histological grade } \\
\hline Well differe & tiated & $46(8.8)$ \\
\hline Moderately & differentiated & $174(33.1)$ \\
\hline Poorly diffe & entiated & $63(12.0)$ \\
\hline Unknown & & $242(46.1)$ \\
\hline \multicolumn{3}{|c|}{ Extent of pulmonary resection } \\
\hline Lobectomy & or wedge resection & 381 (72.6) \\
\hline Pneumone & omy or bilobectomy & $144(27.4)$ \\
\hline \multicolumn{3}{|c|}{ Visceral pleural invasion } \\
\hline Absent & & $351(66.9)$ \\
\hline Present & & $121(23.0)$ \\
\hline Unknown & & $53(10.1)$ \\
\hline Number of $L$ & Is dissected/sampled & $15.4 \pm 10.1$ \\
\hline$L N \leqslant 15$ & & $298(56.7)$ \\
\hline$L N>15$ & & $222(42.3)$ \\
\hline Unknown & & $5(1.0)$ \\
\hline
\end{tabular}

survivals for patients with tumour size $>3$ to $\leqslant 5 \mathrm{~cm},>5$ to $\leqslant 7 \mathrm{~cm}$, and $>7 \mathrm{~cm}$ were 59.6 months (95\% CI $48.762-$ 70.505 months), 43.9 months (95\% CI 31.318-56.415 months), and 23.7 months (95\% CI 11.837-35.629 months), respectively (fig. 2). The median survivals for patients with and without VPI were 54.4 months (95\% CI 41.705-67.162 months) and 49.0 months (95\% CI 41.705-67.162 months), respectively (fig. 3). VPI was not associated with an increased hazard of death in this population of patients $(p=0.424)$.

Variables with $p$-value $<0.05$ after the univariate analysis were entered into multivariate analysis. Histological type was also entered for mutual adjustment. Only age (HR 1.028, 95\% CI $1.014-1.043 ; \mathrm{p}<0.001)$, tumour size $(\mathrm{p}=0.002)$, extent of pulmonary resection (HR for bilobectomy and pneumonectomy $1.456,95 \%$ CI 1.149-1.846; $p=0.002)$, histological type $(p=0.005)$, and number of mediastinal lymph nodes dissected/sampled

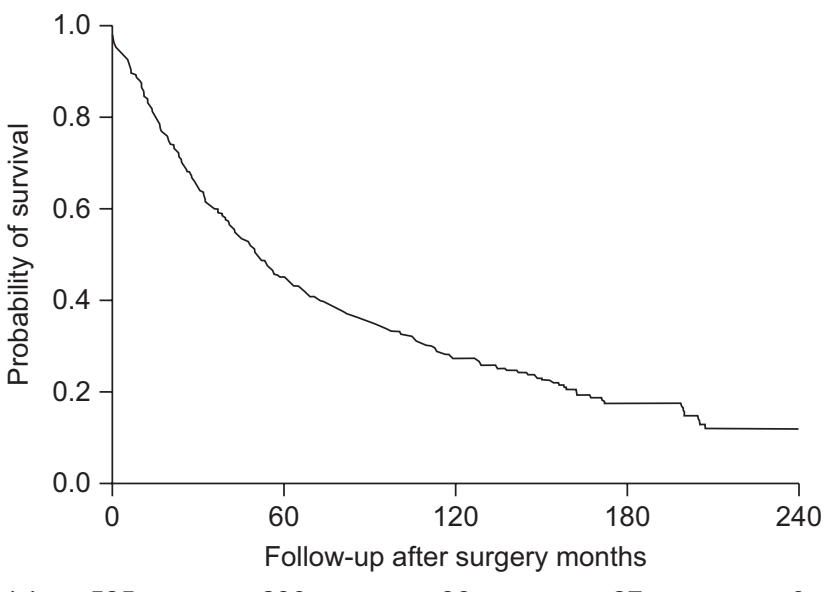

$\begin{array}{llll}\text { At risk n } & 525 & 230 & 86\end{array}$

9

FIGURE 1. Cumulative probability of overall survival in patients with surgically resected stage IB nonsmall cell lung cancer with a diameter $>3 \mathrm{~cm}$.

(HR 0.983, 95\% CI 0.971-0.994; $\mathrm{p}=0.004$ ) were still significant prognostic indicators in multivariate analysis (table 4). Patients with tumour size $>7 \mathrm{~cm}$ (HR 1.724, 95\% CI 1.231-2.415) and >5 to $\leqslant 7 \mathrm{~cm}$ (HR 1.377, 95\% CI 1.059-1.790) had a worse survival than those with tumour size $>3$ to $\leqslant 5 \mathrm{~cm}(\mathrm{p}=0.002)$. Patients with adenocarcinoma (HR 1.377, 95\% CI 1.059-1.790) had a worse survival than those with squamous cell carcinoma $(\mathrm{p}=0.005)$.

\section{DISCUSSION}

This study investigated the prognostic role of conventional clinicopathological factors in patients with resected stage I NSCLC of diameter $>3 \mathrm{~cm}$. The 5- and 10-yr overall survival rates were $44.9 \%$ and $27.3 \%$, respectively. Age, tumour size, extent of pulmonary resection, histological type and number of mediastinal lymph nodes dissected/sampled were significant predictors for overall survival in multivariate analysis. VPI did not influence overall survival.

The number of mediastinal lymph nodes dissected/sampled alternatively represents the quality of lymphadenectomy and affects the survival rate for patients with resected stage I NSCLC [26, 27]. In our previous study [26], we have demonstrated that number of mediastinal lymph nodes dissected/sampled was a prognostic factor for overall survival in resected stage I NSCLC with a diameter $\leqslant 3 \mathrm{~cm}$. For resected stage I NSCLC with a diameter of $\leqslant 3 \mathrm{~cm}$, patients with $\leqslant 15$ mediastinal lymph nodes dissected/sampled had worse survival outcome than those with $>15$ [26]. In the current study, number of mediastinal lymph nodes dissected/ sampled was entered into univariate and multivariate analyses as a continuous variable. Patients with more mediastinal lymph nodes dissected/sampled had better survival. Number of mediastinal lymph nodes dissected/sampled could be used as a marker of adequate mediastinal lymph node dissection/ sampling and a prognostic predictor in early stage NSCLC with larger tumour size.

The prognostic factors subcommittee of the International Staging Committee of the IASLC has published a paper regarding the impact of additional prognostic factors in NSCLC [30]. 


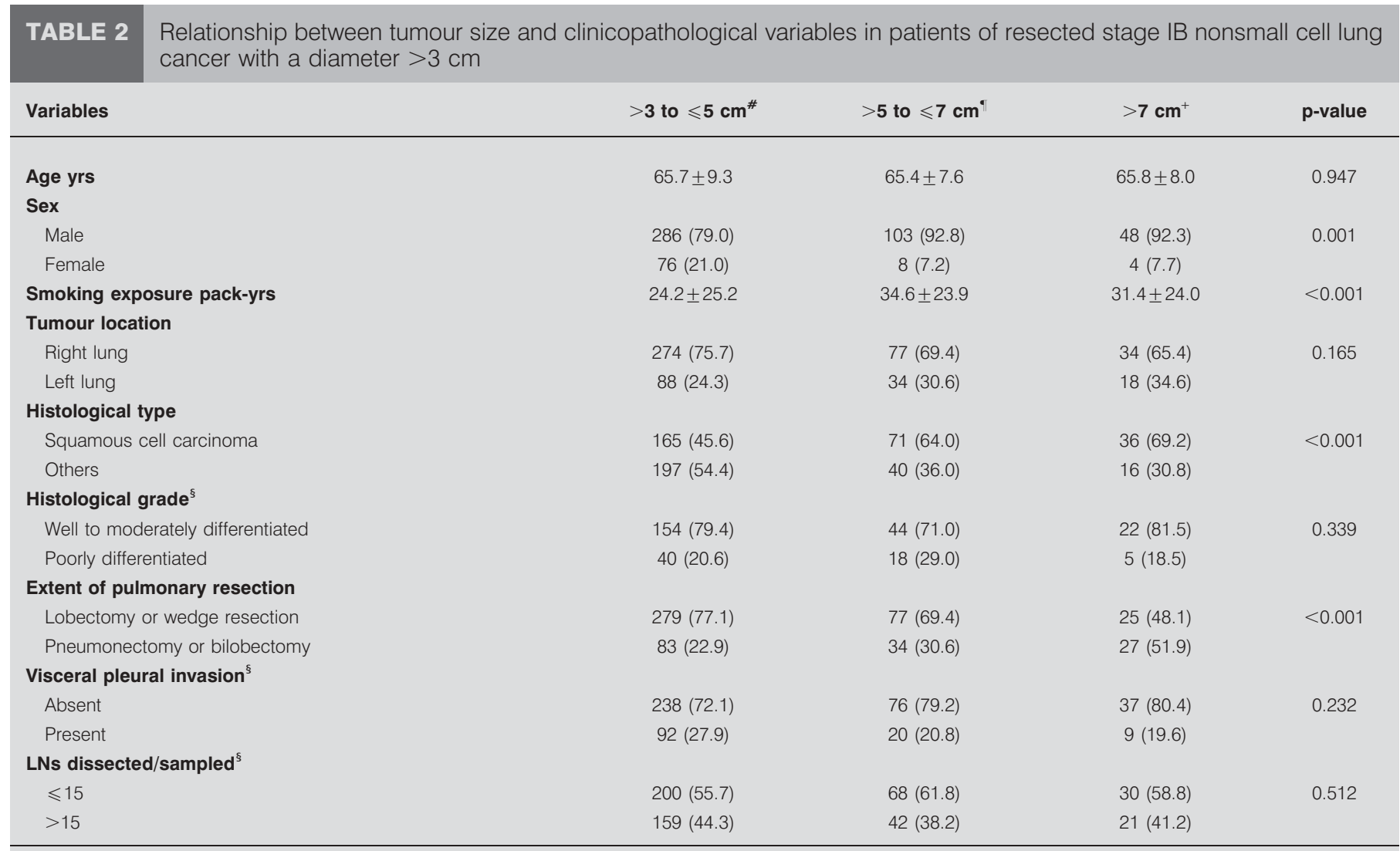

Data are presented as mean \pm SD or $n(\%)$, unless otherwise stated. LN: lymph node. ${ }^{\#}: n=362 ;{ }^{\top}: n=111 ;{ }^{+}: n=52 ;^{\text {s. }}$ : data are lacking in some patients for these variables.

Histological cell type was a significant prognostic factor in stage IIIA NSCLC, with squamous cell carcinoma having a better prognosis in comparison to other cell types [30]. For early stage (stage I-II) NSCLC in their study, histological cell type was not a prognostic factor for survival in their study [30]. In our report, squamous cell carcinoma is a better prognostic factor for stage IB NSCLC $>3 \mathrm{~cm}$.

Tumour size is a significant prognostic factor for stage I NSCLC $[13,18,24]$. The use of $3 \mathrm{~cm}$ as a cut-off value has been applied since 1997, to divide patients with T1N0M0 (as stage IA) from those with T2N0M0 (as stage IB) [2]. Further categorisation of tumour size in stage I NSCLC has been proposed in many studies [5-7, 24, 31-33]. PADILLA et al. [5] reported that tumour size was the only predictor for worse survival in stage IB patients. JONES et al. [4] reported that increased tumour size and histological grade were significant independent predictors of a worse overall survival in stage IB NSCLC. CARBONE et al. [6] demonstrated that a tumour size of $>5 \mathrm{~cm}$ was a poor prognostic factor in T2 NSCLC. For the revision of the seventh edition of the TNM staging system, the IASLC lung cancer staging project committee has recommended that T2 tumours be classified into T2a $(>3$ to $\leqslant 5 \mathrm{~cm})$, T2b $(>5$ to $\leqslant 7 \mathrm{~cm})$, and T3 $(>7 \mathrm{~cm})$ [10-12]. In our study, tumour size was a significant predictor for overall survival in resected stage IB NSCLC with a diameter $>3 \mathrm{~cm}$. Patients with tumour size $>7 \mathrm{~cm}$ and $>5$ to $\leqslant 7 \mathrm{~cm}$ survived a shorter period than those with tumour size $>3$ to $\leqslant 5 \mathrm{~cm}$. Our results support the IASLC proposals for the revision of the T2 tumours in the seventh edition of the TNM classification for lung cancer. We further showed that patients with tumour size $>5 \mathrm{~cm}$ had more squamous cell carcinoma than those with tumour size $>3$ to $\leqslant 5 \mathrm{~cm}$. Patients with larger tumour size also more frequently underwent extensive pulmonary resection (pneumonectomy or bilobectomy).

The reported frequency of VPI in stage I NSCLC patients ranged $18-21 \%[19,23]$. JonEs et al. [4] reported that the frequency of VPI in patients with stage IB NSCLC was $36.4 \%$, while KANG et al. [20] reported only $23 \%$. In our study, the frequency of VPI in stage IB NSCLC with a diameter $>3 \mathrm{~cm}$ was $25.6 \%$ (121 out of 472 patients). The relationship between frequency of VPI and tumour size has not been well demonstrated. In the study reported by MANAC'H et al. [19], the frequency of VPI significantly increased as tumour size increased $(10 \%$ in tumour size $\leqslant 3 \mathrm{~cm}, 19.6 \%$ in $>3$ to $\leqslant 5 \mathrm{~cm}$ and $33 \%$ in $>5 \mathrm{~cm}$ ). SHIMIZU et al. [23] also demonstrated that tumours with a diameter $>3 \mathrm{~cm}$ had higher frequency of VPI. However, no correlation between tumour size and VPI was found in the report by KANG et al. [20]. Our results showed that there was no association between VPI and tumour size in stage IB NSCLC with a diameter $>3 \mathrm{~cm}$.

Although VPI is the most common criteria of the three nonsize-based T2 descriptors [4, 13, 14], its prognostic value for survival has remained controversial [4, 6, 7, 13, 18, 23-25]. VPI was shown to correlate with a higher frequency of mediastinal lymph node involvement, and thus a poor survival [19, 20, 23]. 


\begin{tabular}{|c|c|c|}
\hline \multicolumn{3}{|c|}{$\begin{array}{l}\text { Univariate analysis for overall survival in patients } \\
\text { with resected stage IB nonsmall cell lung cancer } \\
\text { with a diameter }>3 \mathrm{~cm}\end{array}$} \\
\hline Variables & Hazard ratio $(95 \% \mathrm{Cl})$ & p-value \\
\hline Age yrs ${ }^{\#}$ & $1.020(1.008-1.033)$ & 0.001 \\
\hline \multicolumn{3}{|l|}{ Sex } \\
\hline Female & 1 & 0.019 \\
\hline Male & $1.408(1.057-1.880)$ & \\
\hline Smoking exposure & $1.004(1.000-1.007)$ & 0.037 \\
\hline \multicolumn{3}{|l|}{ Location } \\
\hline Left & 1 & 0.378 \\
\hline Right & $0.907(0.730-1.127)$ & \\
\hline Tumour size (continuous variable) $\mathrm{cm}$ & $1.115(1.067-1.165)$ & $<0.001$ \\
\hline \multicolumn{3}{|l|}{ Tumour size $\mathrm{cm}$} \\
\hline$>3$ to $\leqslant 5$ & 1 & $<0.001$ \\
\hline$>5$ to $\leqslant 7$ & $1.282(1.006-1.632)$ & \\
\hline$>7$ & $1.831(1.340-2.502)$ & \\
\hline \multicolumn{3}{|l|}{ Histological type } \\
\hline Squamous cell carcinoma & 1 & 0.226 \\
\hline Adenocarcinoma & $1.053(0.855-1.298)$ & \\
\hline Others & $1.410(0.953-2.105)$ & \\
\hline \multicolumn{3}{|l|}{ Histological grade } \\
\hline Well to moderately differentiated & 1 & 0.237 \\
\hline Poorly differentiated & $1.213(0.880-1.672)$ & \\
\hline \multicolumn{3}{|l|}{ Extent of pulmonary resection } \\
\hline Sublobar resection or lobectomy & 1 & 0.004 \\
\hline Bilobectomy or pneumonectomy & $1.374(1.109-1.703)$ & \\
\hline \multicolumn{3}{|l|}{ Visceral pleural invasion } \\
\hline Absent & 1 & 0.424 \\
\hline Present & $0.902(0.700-1.162)$ & \\
\hline Number of LNs dissected/sampled ${ }^{+}$ & $0.988(0.978-0.999)$ & 0.035 \\
\hline \multicolumn{3}{|c|}{$\begin{array}{l}\mathrm{LN} \text { : lymph node. }{ }^{*} \text { : the hazard ratio associated with age is that the increase in } \\
\text { hazard is associated with a } 1 \text {-yr increase in age; " : the hazard ratio associated } \\
\text { with smoking exposure is an increased hazard per } 1 \text { pack-yr of additional } \\
\text { smoking; }{ }^{+} \text {: the hazard ratio associated with number of LNs dissected/ } \\
\text { sampled is an increased hazard per } 1 \mathrm{LN} \text { of additional LN dissection/ } \\
\text { sampling. }\end{array}$} \\
\hline
\end{tabular}

However, the impact of VPI in stage I NSCLC is less clear. The effect of tumour size on the impact of VPI has remained unclear. There are only a few reports regarding this issue, and the results were inconsistent [22, 24]. Some studies have demonstrated VPI to be a poor prognostic factor in stage I or stage IB NSCLC [18-20, 23]. Ou et al. [14] reported that presence of VPI, hilar atelectasis or obstructive pneumonitis in $\mathrm{T} 2$ tumours $>3 \mathrm{~cm}$ is an independent poor prognostic factor for survival. However, VPI could not be separated from hilar atelectasis and obstructive pneumonitis in their database [14, 34]. Therefore, the specific effect of VPI in stage IB NSCLC could not be analysed in their study [14]. LÓPEZ-ENCUENTRA et al. [13] reported that VPI was not a prognostic factor in stage I NSCLC. JONES et al. [4] demonstrated that VPI did not influence overall survival in stage IB NSCLC. In the study reported by MARTINI et al. [24], it was shown that VPI, although a contributing adverse factor in patients with larger tumours, did not influence overall survival in stage I NSCLC with a diameter $>3 \mathrm{~cm}(\mathrm{p}=0.18)$. The International Staging

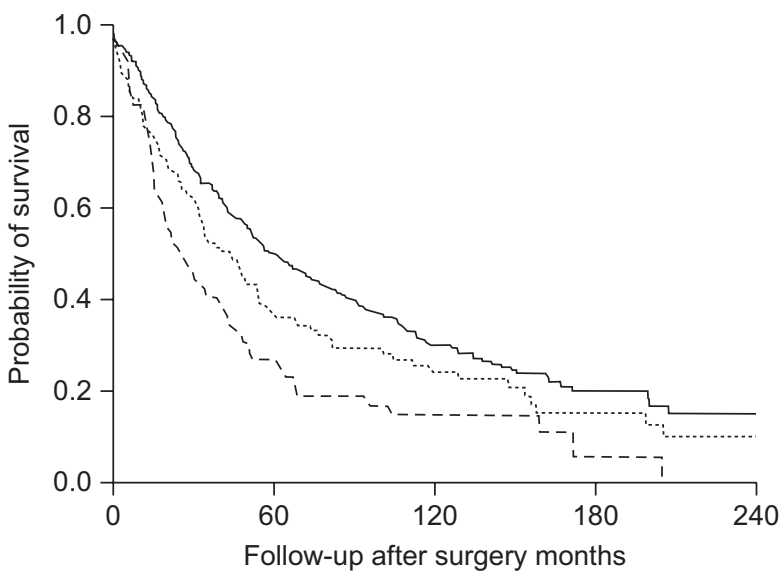

At risk $n$

$\begin{array}{lrrrrr}>3 \text { to } \leq 5 \mathrm{~cm} & 362 & 176 & 63 & 19 & 5 \\ >5 \text { to } \leq 7 \mathrm{~cm} & 111 & 40 & 17 & 7 & 4 \\ >7 \mathrm{~cm} & 52 & 14 & 6 & 1 & 0\end{array}$

FIGURE 2. Overall survival in patients with resected stage I nonsmall cell lung cancer with a diameter $>3 \mathrm{~cm}$ grouped according to tumour size ( $>3$ to $\leqslant 5(-)$, $>5$ to $\leqslant 7(\cdots \cdots) \mathrm{cm}$ and $>7 \mathrm{~cm}(----)$. The log-rank test was used to compare between groups. $>3$ to $\leqslant 5 \mathrm{~cm}$ versus $>7 \mathrm{~cm}: \mathrm{p}<0.001 ;>3$ to $\leqslant 5 \mathrm{~cm}$ versus $>5$ to $\leqslant 7 \mathrm{~cm}: \mathrm{p}=0.044 ;>5$ to $\leqslant 7 \mathrm{~cm}$ versus $>7 \mathrm{~cm}: \mathrm{p}=0.062$.

Committee of the IASLC has published proposals for the definition of VPI as invasion beyond the elastic layer (PL1) including invasion to the visceral pleural surface (PL2) [17]. They also recommend the use of elastic stains in cases when the status of VPI is indeterminate [17]. In the current study, we used elastic stains in documenting VPI in sections where the status of invasion is indeterminate by haematoxylin and eosin stains. VPI was not a prognostic factor of overall survival in resected stage IB NSCLC with a diameter $>3 \mathrm{~cm}$. Our previous study has demonstrated that VPI was not a prognostic factor for overall survival in stage I NSCLC with a diameter of $\leqslant 3 \mathrm{~cm}$ [26]. Compared with the patients of stage I NSCLC

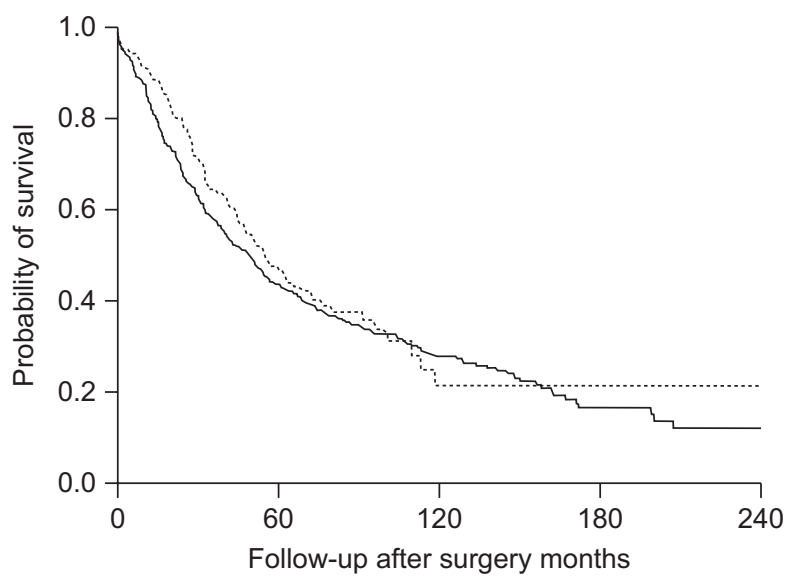

At risk $n$

$\begin{array}{lllll}\text { Without VPI } & 351 & 151 & 66 & 17\end{array}$

$\begin{array}{llllll}\text { With VPI } & 121 & 54 & 6 & 2 & 1\end{array}$

FIGURE 3. Overall survival in patients with resected stage I nonsmall cell lung cancer with a diameter $>3 \mathrm{~cm}$ with $(\cdots \cdots)$ or without $(-)$ visceral pleural invasion (VPI). $p=0.424$ (log-rank test). 


\begin{tabular}{|c|c|c|c|}
\hline TABLE 4 & \multicolumn{3}{|c|}{$\begin{array}{l}\text { Multivariate analysis for overall survival in } \\
\text { patients with resected stage IB nonsmall cell } \\
\text { lung cancer with a diameter }>3 \mathrm{~cm}\end{array}$} \\
\hline \multicolumn{2}{|l|}{ Variables } & Hazard ratio $(95 \% \mathrm{Cl})$ & p-value \\
\hline \multicolumn{2}{|l|}{ Age yrs $^{\#}$} & $1.028(1.014-1.043)$ & $<0.001$ \\
\hline \multicolumn{4}{|l|}{ Sex } \\
\hline \multicolumn{2}{|l|}{ Female } & 1 & 0.582 \\
\hline \multicolumn{2}{|l|}{ Male } & $1.100(0.784-1.543)$ & \\
\hline \multicolumn{2}{|c|}{ Smoking exposure } & $1.003(0.999-1.007)$ & 0.131 \\
\hline \multicolumn{4}{|c|}{ Tumour size $\mathrm{cm}$} \\
\hline \multicolumn{2}{|l|}{$>3$ to $\leqslant 5$} & 1 & 0.002 \\
\hline \multicolumn{2}{|l|}{$>5$ to $\leqslant 7$} & $1.377(1.059-1.790)$ & \\
\hline \multicolumn{2}{|l|}{$>7$} & $1.724(1.231-2.415)$ & \\
\hline \multicolumn{4}{|c|}{ Extent of pulmonary resection } \\
\hline \multicolumn{2}{|c|}{ Sublobar resection or lobectomy } & 1 & 0.002 \\
\hline \multicolumn{2}{|c|}{ Bilobectomy or pneumonectomy } & $1.456(1.149-1.846)$ & \\
\hline \multicolumn{4}{|c|}{ Histological type } \\
\hline \multicolumn{2}{|c|}{ Squamous cell carcinoma } & 1 & 0.005 \\
\hline \multicolumn{2}{|c|}{ Adenocarcinoma } & $1.377(1.059-1.790)$ & \\
\hline \multicolumn{2}{|l|}{ Others } & $1.724(1.231-2.415)$ & \\
\hline \multicolumn{2}{|c|}{ Number of LNs dissected/sampled" } & $0.983(0.971-0.994)$ & 0.004 \\
\hline \multicolumn{4}{|c|}{$\begin{array}{l}\mathrm{LN} \text { : lymph node. }{ }^{\#}: \text { the hazard ratio associated with age is that the increase in } \\
\text { hazard is associated with a } 1 \text {-yr increase in age; }{ }^{~} \text { : the hazard ratio associated } \\
\text { with number of LNs dissected/sampled is an increased hazard per } 1 \mathrm{LN} \text { of } \\
\text { additional LN dissection/sampling. }\end{array}$} \\
\hline
\end{tabular}

with a diameter $>3 \mathrm{~cm}$, the overall survival was significantly better in patients of stage I NSCLC $\leqslant 3 \mathrm{~cm}$ in diameter with VPI $(p=0.012)$. In the current study, we further showed that tumour size is the most determined factor of survival in stage IB NSCLC with a diameter $>3 \mathrm{~cm}$. Therefore, small tumours $(\leqslant 3 \mathrm{~cm})$ of stage IB NSCLC with VPI should be treated as T1 disease (stage IA) but not T2 disease. VPI did not influence overall survival in larger tumour $(>3 \mathrm{~cm})$ of stage IB NSCLC.

There are some limitations of this study that should be mentioned. This is a retrospective study with a long study period. Data are lacking in some patients for some variables. The information of whether pre-operative mediastinoscopy was done was only available in $37 \%$ of patients in the study. Not all patients had received radical mediastinal lymph node dissection in our cohort. However, we provided the number of mediastinal lymph nodes dissected/sampled in nearly all patients to alternatively represent the quality of lymphadenectomy. Furthermore, the lack of data on the frequency of other T2 descriptors (tumours that involve the main bronchus $\geqslant 2 \mathrm{~cm}$ distal to the carina and tumours that result in associated atelectasis and obstructive pneumonitis that extends to the hilar region but does not involve the entire lung radiographically) in the study population was another weakness of our study. However, the main criterion of non-sizebased T2 descriptors is VPI $[4,13,14]$. NSCLC is rarely staged as stage IB only according to hilar atelectasis and obstructive pneumonitis $[4,13,14,34]$.

In conclusion, age, tumour size, extent of pulmonary resection, histological type and number of mediastinal lymph nodes dissected/sampled were prognostic factors for overall survival in resected stage IB NSCLC with a diameter $>3 \mathrm{~cm}$. We suggest subclassification of stage IB NSCLC with a diameter $>3 \mathrm{~cm}$ according to tumour size, regardless of VPI.

\section{STATEMENT OF INTEREST}

None declared.

\section{ACKNOWLEDGEMENTS}

The authors would like to thank L-S. Wang (Dept of Surgery, Shuang Ho Hospital, Taipei, Taiwan) for contributing to this article. We also thank J-H. Lin (Division of Thoracic Surgery, Dept of Surgery, Taipei Veterans General Hospital, Taipei, Taiwan) for his assistance in data collection.

\section{REFERENCES}

1 Mountain CF, Carr DT, Anderson WA. A system for the clinical staging of lung cancer. Am J Roentgenol Roentgenol Radium Ther Nucl Med 1974; 120: 130-138.

2 Mountain CF. Revisions in the international system for staging lung cancer. Chest 1997; 111: 1710-1717.

3 Sobin L, Wittekind Ch, eds. TNM Classification of Malignant Tumors. 6th Edn. New York, Wiley-Liss, 2002: 99-103.

4 Jones DR, Daniel TM, Denlinger CE, et al. Stage IB nonsmall cell lung cancers: are they all the same? Ann Thorac Surg 2006; 81: 1958-1962.

5 Padilla J, Calvo V, Peñalver JC, et al. Survival and risk model for stage IB non-small cell lung cancer. Lung Cancer 2002; 36: 43-48.

6 Carbone E, Asamura H, Takei H, et al. T2 tumors larger than five centimeters in diameter can be upgraded to T3 in non-small cell lung cancer. J Thorac Cardiovasc Surg 2001; 122: 907-912.

7 Takeda S, Fukai S, Komatsu H, et al. Impact of large tumor size on survival after resection of pathologically node negative (pN0) nonsmall cell lung cancer. Ann Thorac Surg 2005; 79: 1142-1146.

8 American Joint Committee on Cancer. AJCC Cancer Staging Manual. $7^{\text {th }}$ Edn. New York, Springer, 2010.

9 International Union Against Cancer. TNM Classification of Malignant Tumours. $7^{\text {th }}$ Edn. Oxford, Wiley-Blackwell, 2009.

10 Rami-Porta R, Ball D, Crowley J, et al. The IASLC Lung Cancer Staging Project: proposals for the revision of the T descriptors in the forthcoming (seventh) edition of the TNM classification for lung cancer. J Thorac Oncol 2007; 2: 593-602.

11 Groome PA, Bolejack V, Crowley JJ, et al. The IASLC Lung Cancer Staging Project: validation of the proposals for revision of the T, N, and $\mathrm{M}$ descriptors and consequent stage groupings in the forthcoming (seventh) edition of the TNM classification of malignant tumours. J Thorac Oncol 2007; 2: 694-705.

12 Goldstraw P, Crowley J, Chansky K, et al. The IASLC Lung Cancer Staging Project: proposals for the revision of the TNM stage groupings in the forthcoming (seventh) edition of the TNM Classification of malignant tumours. J Thorac Oncol 2007; 2: 706-714

13 López-Encuentra A, Gómez de la Cámara A, Rami-Porta R, et al. Previous tumour as a prognostic factor in stage I non-small cell lung cancer. Thorax 2007; 62: 386-390.

14 Ou SH, Zell JA, Ziogas A, et al. Prognostic significance of the nonsize-based AJCC T2 descriptors: visceral pleura invasion, hilar atelectasis, or obstructive pneumonitis in stage IB non-small cell lung cancer is dependent on tumor size. Chest 2008; 133: 662-669.

15 Hammar SP. Common Tumors. In: Dail DH, Hammar SP, eds. Pulmonary Pathology. 2nd Edn. New York, Springer-Verlag, 1994; p. 1138.

16 Hammar SP. Common Tumors. In: Dail DH, Hammar SP, eds. Pulmonary Pathology. 1st Edn. New York, Springer-Verlag, 1988. pp. 727-845.

17 Travis WD, Brambilla E, Rami-Porta R, et al. Visceral pleural invasion: pathologic criteria and use of elastic stains: proposal for 
the 7th edition of the TNM classification for lung cancer. J Thorac Oncol 2008; 3: 1384-1390.

18 Harpole DH Jr, Herndon JE II, Young WG Jr, et al. Stage I nonsmall cell lung cancer. Cancer 1995; 76: 787-796.

19 Manac'h D, Riquet M, Medioni J, et al. Visceral pleura invasion by non-small cell lung cancer: an underrated bad prognostic factor. Ann Thorac Surg 2001; 71: 1088-1093.

20 Kang JH, Kim KD, Chung KY. Prognostic value of visceral pleura invasion in non-small cell lung cancer. Eur J Cardiothorac Surg 2003; 23: $865-869$.

21 Osaki T, Nagashima A, Yoshimatsu T, et al. Visceral pleural involvement in non-small cell lung cancer: prognostic significance. Ann Thorac Surg 2004; 77: 1769-1773.

22 Shimizu K, Yoshida J, Nagai K, et al. Visceral pleural invasion classification in non-small cell lung cancer: a proposal on the basis of outcome assessment. J Thorac Cardiovasc Surg 2004; 127: 1574-1578.

23 Shimizu K, Yoshida J, Nagai K, et al. Visceral pleural invasion is an invasive and aggressive indicator of non-small cell lung cancer. J Thorac Cardiovasc Surg 2005; 130: 160-165.

24 Martini N, Bains MS, Burt ME, et al. Incidence of local recurrence and second primary tumors in resected stage I lung cancer. J Thorac Cardiovasc Surg 1995; 109: 120-129.

25 Padilla J, Calvo V, Penalver JC, et al. Surgical results and prognostic factors in early non-small cell lung cancer. Ann Thorac Surg 1997; 63: 324-326.

26 Hung J-J, Wang C-Y, Huang M-H, et al. Prognostic factors in resected stage I non-small cell lung cancer with a diameter of $3 \mathrm{~cm}$ or less: visceral pleural invasion did not influence overall and disease-free survival. J Thorac Cardiovasc Surg 2007; 134: 638-643.

$27 \mathrm{Wu} \mathrm{YC}$, Lin CF, Hsu WH, et al. Longterm results of pathological stage I non-small cell lung cancer: validation of using the number of totally removed lymph nodes as a staging control. Eur J Cardiothorac Surg 2003; 24: 994-1001.

28 World Health Organization: Histological typing of lung tumors. 2nd Edn. Geneva, World Health Organization, 1981.

29 Kaplan EL, Meier P. Nonparametric estimation for incomplete observations. J Am Stat Assoc 1958; 53: 457-481.

30 Sculier JP, Chansky K, Crowley JJ, et al. The impact of additional prognostic factors on survival and their relationship with the anatomical extent of disease expressed by the 6th Edition of the TNM Classification of Malignant Tumors and the proposals for the 7th Edition. J Thorac Oncol 2008; 3: 457-466.

31 Birim O, Kappetein AP, Takkenberg JJ, et al. Survival after pathological stage IA non- small cell lung cancer: Tumor size matters. Ann Thorac Surg 2005; 79: 1137-1141.

32 Port JL, Kent MS, Korst RJ, et al. tumor size predicts survival within stage IA non-small cell lung cancer. Chest 2003; 124: 1828-1833.

33 López-Encuentra A, Duque-Medina JL, Rami-Porta R, et al. Staging in lung cancer: is $3 \mathrm{~cm}$ a prognostic threshold in pathologic stage I non-small cell lung cancer? A multicenter study of 1,020 patients. Chest 2002; 121: 1515-1520.

34 Hung JJ, Liu JS, Wu YC, et al. The effect of tumor size on non-sizebased descriptors in staging of stage I non-small cell lung cancer. Chest 2009; 135: 1695. 